\title{
Pengantar
}

MSDM (Manajemen Sumber Daya Manusia) adalah manajemen yang mempelajari khusus peranan serta hubungan manusia dalam suatu organisasi perusahaan. Unsur MSDM adalah yang termasuk tenaga kerja atau karyawan pada suatu perusahaan adalah manusia. Jadi MSDM ini hanya fokus terhadap tenaga kerja seorang manusia.

Menurut Drs. Malayu S.P. Hasibuan, MSDM ( Manajemen Sumber Daya Manusia) adalah suatu ilmu yang mengatur suatu hubungan serta peranan tenaga kerja agar lebih efisien dan efektif agar dapat membantu terwujudnya suatu tujuan perusahaan, karyawan, dan juga masyarakat.

Pengertian manajemen menurut Marwansyah yaitu pendayagunaan SDM didalam suatu organisasi yang dilaksanakan melalui fungsi-fungsi perencanaan SDM, pengembangan SDM, perencanaan dan pengembangan karir, seleksi dan rekrutmen, pemberian kompensasi dan kesejahteraan, hubungan industrial, serta kesehatan dan keselamatan kerja.

Menurut Samsuni MSDM adalah pelaksanaan, pengontrolan serta rencana pengorganisasian SDM (Sumber Daya Manusia) dalam mencapai suatu tujuan yang efektif dan efisien suatu organisasi.

Menurut Kastra (2012) Komponen MSDM terdiri dari pimpinan, pengusaha, dan karyawan.

Metode pendekatan MSDM yaitu pendekatan mekanis, pendekatan paternalis, dan pendekatan sistem sosial.

a. Pendekatan mekanis

Adalah tenaga manusia yang dapat tergantikan dengan tenaga mesin untuk melakukan pekerjaan. Penggantian tersebut berdasarkan pertimbangan efektifitas, kemanusiaan, ekonomis, serta kemampuan yang lebih baik dan juga lebih besar.

b. Pendekatan paternalis

Adalah manajer yang bertugas untuk memberi pengarahan kepada bawahannya. Manajer juga bertindak seperti kepala keluarga kepada seluruh angota keluarganya. Para bawahan-bawahan manajer seharusnya diperlakukan dengan baik, segala fasilitas diberikan, serta bawahan tersebut dianggap juga sebagai keluarganya. 
c. Pendekatan sistem sosial

Pendekatan sistem sosial memandang bahwa perusahaan/organisasi adalah suatu sistem yang mempunyai sifat kompleks yang juga beroperasi dalam suatu lingkungan yang kompleks juga dan biasanya disebut sebagai suatu sistem yang beroperasi di luar.

MSDM berfungsi sebagai pengarahan, pengendalian, pengintegrasian, pengembangan, kompensasi, pengorganisasian, pemeliharaan, kedisiplinan, perencanaan, pengadaan serta pemberhentian.

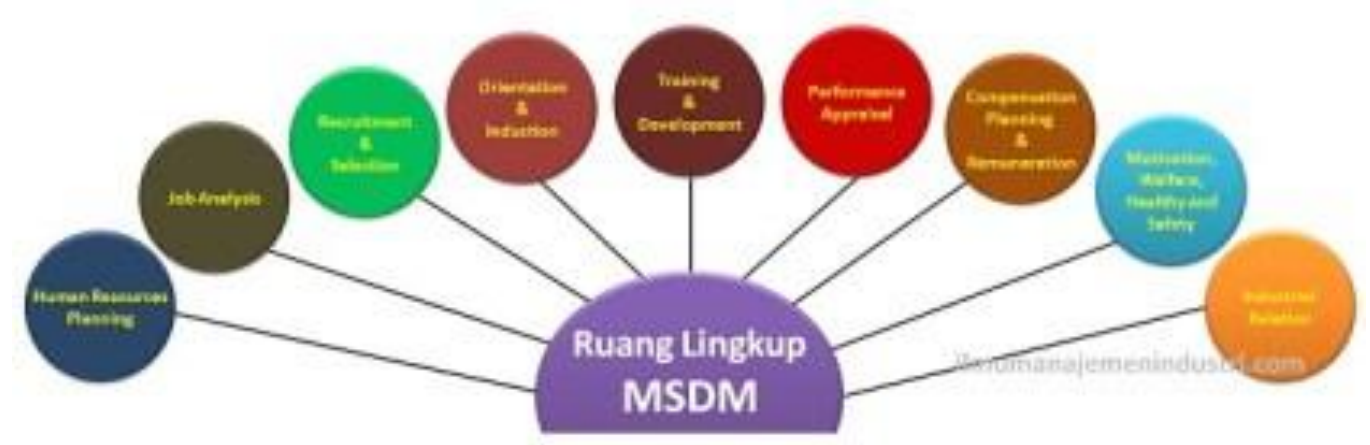

Gambar 1. Ruang Lingkup MSDM (Budi Kho, 2017)

\section{Pentingnya Pengembangan}

Pengembangan adalah suatu fungsi operasional dari MSDM. Pengembangan Karyawan (baru/lama) seharusnya dilakukan secara terancang serta juga berkesinambungan. Agar pelaksanaan pengembangan dapat berjalan dengan baik, yang dilakukan terlebih dahulu yaitu menetapkan suatu program yangdapat mencapai pengembangan karyawan. Hendaknya program pengembangan karyawan disusun melihat kepada segala metode ilmiah serta berpedoman kepada keterampilan. Dimana saat ini dibutuhkan oleh perusahaan maupun untuk masa selanjutnya dan juga program pengembangan karyawan harus disusun dengan cermat. Pengembangan bertujuan untuk meningkatkan kemampuan teoritas, teknis, moral karyawan dan konseptual supaya baik prestasi kerjanya serta agar mencapai hasil yang 
diinginkan oleh suatu perusahaan. Tujuan pengembangan menyangkut hal-hal berikut : Efisiensi, Moral, Produktivitas Kerja, Kerusakan, Pelayanan, Balas Jasa, kecelakaan, Karier, Konseptual, Konsumen, serta kepemimpinan.

a. Efisiensi

Pengembangan karyawan yang bertujuan untuk meningkatkan suatu efisiensi bahan baku, waktu, tenaga, serta mengurangi ausnya mesin.

b. Moral

Moral karyawan akan lebih baik dengan adanya program pengembangan karyawan didalam keahlian dan keterampilannya yang sesuai dengan pekerjaan mereka sehingga antusias dalam menyelesaikan pekerjaan .

c. Produktivitas Kerja

Produktivitas kerja seorang karyawan dengan adanya program pengembangan karyawan akan lebih meningkat daripada sebelumnya, serta kualitas dan kuantitas produksinya juga akan semakin baik, karena managerial skill, technical skill, serta human skill karyawan yang akan semakin baik.

d. Kerusakan

Pengembangan karyawan bertujuan juga dalam mengurangi kerusakan suatu barang produksi, serta mesin karena ulah karyawan akan terampil dan ahli dalam melaksanakan semua pekerjaannya.

e. Pelayanan

Pengembangan bertujuan dalam peningkatkan pelayanan yang semakin baik lagi dari seorang karyawan kepada nasabah suatu perusahaan.

f. Balas Jasa

Balas jasa baik dalam bentuk gaji, upah insentif, dan benefits karyawan akan semakin meningkat dengan adanya program pengembangan karena adanya suatu peningkatan prestasi kerja karyawan yang semakin baik daripada sebelumnya.

g. Kecelakaan

Pengembangan bertujuan juga untuk mengurangi tingkat suatu kecelakaan karyawan, agar jumlah biaya tanggungan karyawan sakit yang akan dikeluarkan oleh perusahaan semakin berkurang.

h. Karier

Dengan pengembangan, kesempatan dalam meningkatkan suatu karir karyawan akan semakin besar. 


\section{i. Konseptual}

Manajer semakin cepat dalam mengambil suatu keputusan yang sangat baik dengan adanya pengembangan ini, karena human skill, managerial skil, dan technical skill yang semakin lebih baik.

j. Konsumen

Dengan adanya pengembangan karyawan pastinya akan memberikan suatu manfaat yang lebih baik lagi bagi seluruh masyarakat karena mereka akan memperoleh baik dalam bentuk barang maupun pelayanan yang lebih berkualitas lagi dari sebelumnya.

k. Kepemimpinan

Kepemimpinan manajer dengan adanya pengembangan akan lebih baik didalam human relations-nya, lebih luwes, lebih terarah motivasinya sehingga pembinaan secara vertikal dan horizontal akan semakin lebih baik.

\section{Pengembangan Karyawan}

Prinsip dari suatu pengembangan yaitu peningkatan kemampuan bekerja karyawan serta kualitas karyawan tersebut. Agar suatu pengembangan mencapai hasil yang sangat baik dan juga dengan biaya relatif kecil, seharusnya ditetapkan terlebih dahulu suatu program pengembangan.

Menurut Soetjipto (2006) ada tiga prinsip yang diperhatikan oleh MSDM supaya dalam melaksakan tugas dan kewajiban mengurus serta mengoordinasikan sumber daya manusia dalam suatu organisasi dapat berjalan efektif dan juga efisien.

Menurut Berman, E. M., et al (2001) menyebutkan bahwa ada 7 prinsip sebuah MSDM pelayanan publik yang seharusnya disadari oleh manajer pelayanan publik.

Dalam suatu program pengembangan sebaiknya dituangkan sebuah kebijaksanaan, prosedur, peserta, anggaran, kurikulum, sasaran, dan waktu pelaksanaannya. Dalam program pengembangan ini seharusnya berprinsip pada peningkatan efisiensi kerja dan penigkatan evektivitas kerja karyawan pada suatu jabatannya. Program pengembangan dalam suatu organisasi seharusnya bisa diinformasikan dengan cara yang terbuka kepada semua karyawan agar mereka mempersiapkan dirinya. 
Jenis-jenis pengembangan

a. Pengembangan secara informal

Keinginan dan usaha sendiri atas karyawan dalam melatih serta mengembangkan dirinya dengan mempelajari macam-macam buku literatur yang ada hubungannya dengan pekerjaan mereka ataupun jabatannya. (Riadi, 2016)

b. Pengembangan secara formal

Seorang karyawan yang ditugaskan oleh perusahaan untuk mengikuti latihan atau pedidikan, baik yang dilakukan oleh perusahaan itu sendiri maupun yang diadakan oleh lembaga-lembaga latihan atau pendidikan. (Riadi, 2016)

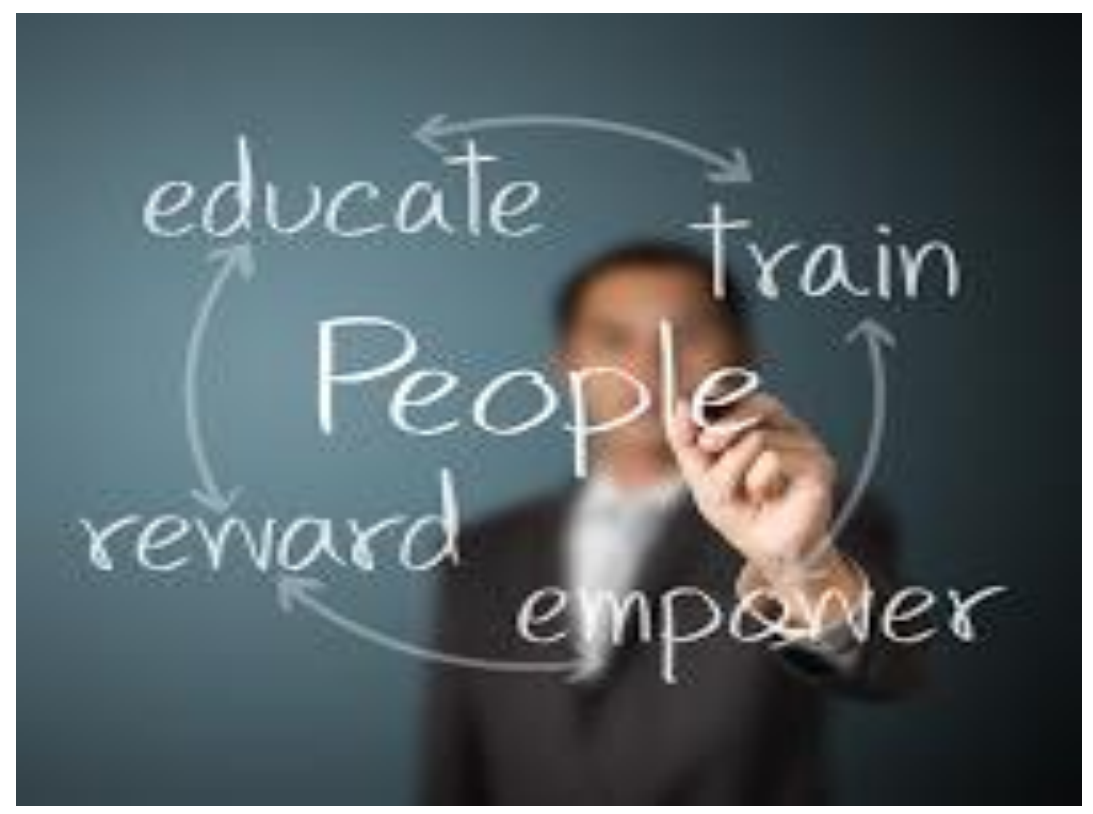

Gambar 2. Pengembangan SDM (Muchlisin Riadi, 2016)

\section{Metode-Metode Pengembangan}

Menurut Hasibuan (2012) metode-metode penembangan ada 2, yaitu :

1. Metode Latihan

Metode latihan harusnya didasarkan kepada kesesuaian kebutuhan pekerjaan yang terkait dengan beberapa faktor, yaitu biaya, waktu, tingkat pendidikan, latar belakang peserta, serta jumlah peserta, dan lain-lain. 


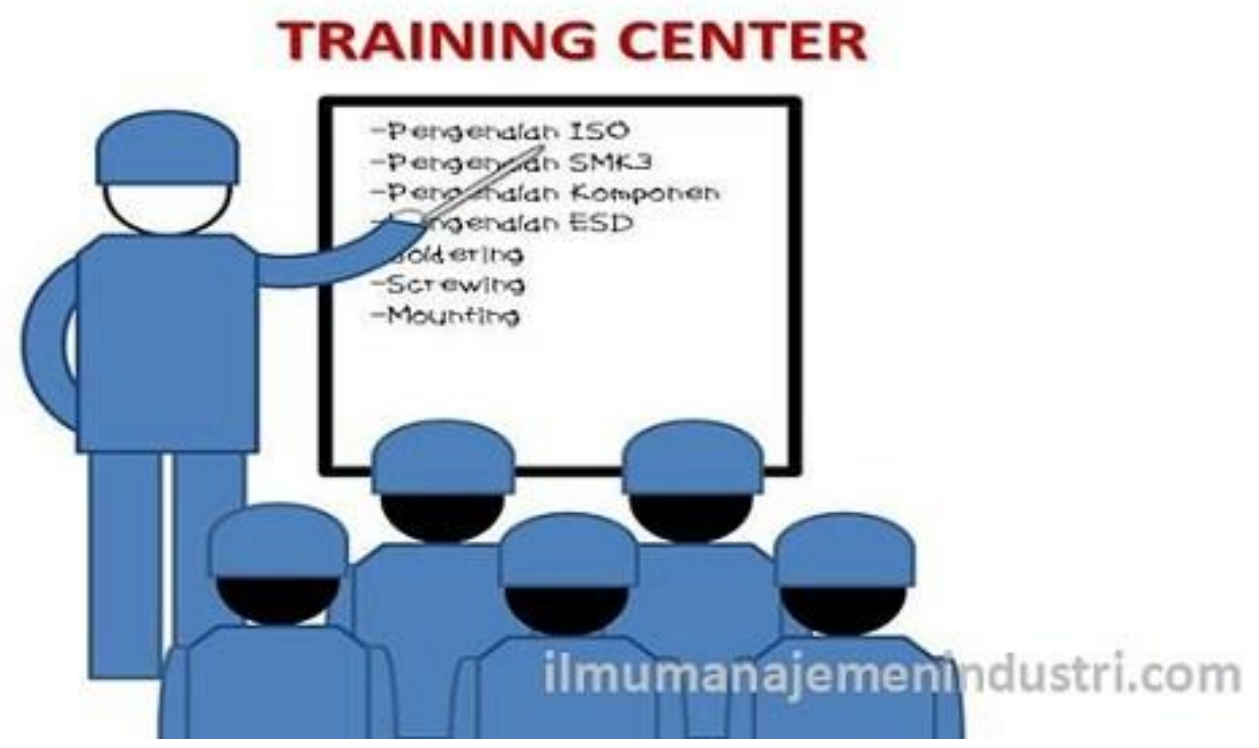

Gambar 3. Pelatihan/ Training ( Budi Kho, 2016)

2. Metode Pendidikan

Metode pendidikan yaitu meningkatkan kecakapan daan keahlian manajer dalam memimpin para bawahannya dengan cara yang efektif. Jika seorang manajer dalam jabatannya efektif pasti akan memperoleh hasil yang sangat optimal. Hal itulah yang dapat memotivasi suatu perusahaan dalam memberikan pendidikan kepada karyawan-karyawan manajerialnya.

Menurut Mursiati (2016) metode-metode penembangan ada 4, yaitu :

1. On The Job Training

Sebuah program pelatihan karyawan yang nantinya dapat memberikan motivasi yang lebih tinggi kepada para peserta untuk belajar serta berlatih.

2. Magang

Metode pelatihan yang didalamnya mengharuskan untuk para pesertanya wajib mengikuti segala bentuk kegiatan yang dilaksanakan oleh para pemangku jabatan-jabatan tertentu.

3. Simulasi

Metode yang dilaksanakan dengana menggunakan mesin atau alat-alat yang dibuat sesui dengan kondisi dan situasi kerja yang sebenarnya.

4. Job Rotation

Dalam metode ini, peserta pelatihan dan juga pengembangan SDM secara berkala akan dipindahkan dari suatu unit kerja tertentu kepada unit kerja yang lainnya. 


\section{Penutup}

MSDM (Manajemen Sumber Daya Manusia) adalah manajemen yang mempelajari peranan serta hubungan manusia dalam suatu organisasi perusahaan. Unsur MSDM adalah yang merupakan tenaga kerja atau karyawan pada suatu perusahaan adalah manusia. Pengembangan adalah fungsi operasional dari MSDM. Pengembangan Karyawan (baru/lama) seharusnya dilakukan secara terancang serta juga berkesinambungan. Agar pelaksanaan pengembangan dapat berjalan dengan baik, yang dilakukan terlebih dahulu yaitu menetapkan suatu program yang dapat mencapai pengembangan karyawan. Hendaknya program pengembangan karyawan disusun melihat kepada segala metode ilmiah serta berpedoman kepada keterampilan. Dimana saat ini dibutuhkan oleh perusahaan maupun untuk masa selanjutnya dan juga program pengembangan karyawan harus disusun dengan cermat. Tujuan pengembangan menyangkut hal-hal berikut : Efisiensi, Moral, Produktivitas Kerja, Kerusakan, Pelayanan, Balas Jasa, kecelakaan, Karier, Konseptual, Kepemimpinan, serta Konsumen. Prinsip dari suatu pengembangan yaitu peningkatan kemampuan bekerja karyawan serta kualitas karyawan tersebut. Agar suatu pengembangan mencapai hasil yang sangat baik dan juga dengan biaya relatif kecil, seharusnya ditetapkan terlebih dahulu suatu program pengembangan. Jenis pengembangan ada 2, yaitu pengembangan yang dilakukan secara informal dan secara formal. Metode- metode untuk pengembangan karyawan meliputi metode pelatihan dan metode pendidikan. 


\section{Daftar Pustaka}

Berman, E. M., et al. (2001). Human Resource Management in Public Service : Paradoxes, Procceses, and Problems. London : Sage Publications. Inc.

Hasibuan, M. (2012). Manajemen Sumber Daya Manusia Edisi Revisi. Jakarta : Bumi Aksara.

Marwansyah. (2010). Manajemen Sumber Daya Manusia. Bandung : Alfabeta.

Soetjipto, B. W. (2006). Manajemen Sumber Daya Manusia : Sebuah Tinjauan Komprehensif. Nilai Stratejik SDM. Seri Manajemen SDM. Jakarta : Lembaga Manajemen Fakultas Ekonomi Universitas Indonesia.

Samsuni. (2017). Manajemen Sumber Daya Manusia. Jurnal Ilmiah Keislamandan Kemasyarakatan, 17(1), 113-124. 
Kastra. (2012, March 4). Komponen Manajemen Sumber Daya Manusia. From https://sites.google.com .

Kho, B. (2016, Sept 21). Pengertian Training (Pelatihan) dan Tahap-tahapnya. From https://ilmumanajemenindustri.com/pengertian-training-pelatihan-tahap-pelatihan/ .

Mursiati. (2016, July 12). 4 Metode Pelatihan dan Pengembangan SDM Karyawan. From https://portal-ilmu.com .

Riadi, M. (2016, Feb 21). Pengembangan Sumber Daya Manusia. From https://www.kajiapustaka.com/2016/02/pengembangan-sumber-daya-manusia.html?m=1 .

https://www.kompasiana.com/diana_bara_cic/5518944f81331128699de891/pengembangankaryawan . 